Article

\title{
Effect of Aluminum Doping Ratios on the Properties of Aluminum-Doped Zinc Oxide Films Deposited by Mist Chemical Vapor Deposition Method Applying for Photocatalysis
}

\author{
Htet Su Wai (D) and Chaoyang Li * \\ School of Systems Engineering, Kochi University of Technology, Kami, Kochi 782-8502, Japan; \\ 246004f@gs.kochi-tech.ac.jp \\ * Correspondence: li.chaoyang@kochi-tech.ac.jp; Tel.: +81-887-57-2106
}

check for updates

Citation: Wai, H.S.; Li, C. Effect of

Aluminum Doping Ratios on the Properties of Aluminum-Doped Zinc Oxide Films Deposited by Mist Chemical Vapor Deposition Method Applying for Photocatalysis.

Nanomaterials 2022, 12, 195. https:// doi.org/10.3390/nano12020195

Academic Editors: Ki-Hyun Kim and Deepak Kukkar

Received: 9 December 2021

Accepted: 3 January 2022

Published: 7 January 2022

Publisher's Note: MDPI stays neutral with regard to jurisdictional claims in published maps and institutional affiliations.

Copyright: () 2022 by the authors. Licensee MDPI, Basel, Switzerland. This article is an open access article distributed under the terms and conditions of the Creative Commons Attribution (CC BY) license (https:// creativecommons.org/licenses/by/ $4.0 /)$.

\begin{abstract}
Aluminum-doped zinc oxide film was deposited on a glass substrate by mist chemical vapor deposition method. The influence of different aluminum doping ratios on the structural and optical properties of zinc oxide film was investigated. The XRD results revealed that the diffraction peak of (101) crystal plane was the dominant peak for the deposited AZO films with the Al doping ratios increasing from $1 \mathrm{wt} \%$ to $3 \mathrm{wt} \%$. It was found that the variation of AZO film structures was strongly dependent on the $\mathrm{Al} / \mathrm{Zn}$ ratios. The intertwined nanosheet structures were obtained when $\mathrm{Zn} / \mathrm{O}$ ratios were greater than $\mathrm{Al} / \mathrm{O}$ ratios with the deposition temperature of $400{ }^{\circ} \mathrm{C}$. The optical transmittance of all AZO films was greater than $80 \%$ in the visible region. The AZO film deposited with $\mathrm{Al}$ doping ratio of $2 \mathrm{wt} \%$ showed the highest photocatalytic efficiency between the wavelength of $475 \mathrm{~nm}$ and $700 \mathrm{~nm}$, with the high first-order reaction rate of $0.004 \mathrm{~min}^{-1}$ under ultraviolet radiation. The mechanism of the AZO film influenced by aluminum doping ratio during mist chemical vapor deposition process was revealed.
\end{abstract}

Keywords: aluminum doping ratio; zinc oxide film; photocatalytic property; mist chemical vapor deposition

\section{Introduction}

In the last decade, the photocatalytic process has been mainly involved in the degradation of chemical pollutants and hazardous industrial waste [1,2]. In 1972, Fujishima et al. observed the unique properties of semiconductor-based photocatalysts on photoelectrochemical water splitting, such as nontoxicity, photosensitivity, and high oxidizing efficiency [3-7]. Since then, many popular metal oxides have been applied as semiconductor photocatalysts, including magnesium oxide, titanium dioxide $\left(\mathrm{TiO}_{2}\right)$, silver oxide, copper (II) oxide and zinc oxide $(\mathrm{ZnO})$, due to their excellent physical and chemical properties [8-13]. Among them, $\mathrm{ZnO}$ has also emerged as a potential semiconductor photocatalyst due to its promising properties, such as a wide bandgap ( $3.37 \mathrm{eV})$ at room temperature, large exciton binding energy (60 meV), super-hydrophilicity, high redox potential, higher surface reactivity, durability, and low cost [14-16]. Moreover, it is well established that the main factor in determining the photocatalytic efficiency of $\mathrm{ZnO}$ is the photo-excitation process, which involves excitation, diffusion, and surface transfer of photogenerated charged carriers [17-19]. However, the faster recombination rate of photogenerated electron-hole pairs can reduce the photocatalytic efficiency of $\mathrm{ZnO}$. It was reported that the recombination rate of electron-hole pairs could be reduced by modifying the surface, introducing the defects or doping with transition metals in $\mathrm{ZnO}$ [20-24]. Compared with other methods, aluminum (Al) doping is expected to be a more efficient method of reducing the electron-hole pairs recombination rate of $\mathrm{ZnO}$ [25-27]. The $\mathrm{Al}$ could be doped into $\mathrm{ZnO}$ films via different methods, such as radio frequency magnetron sputtering, sol-gel method, chemical vapor 
deposition (CVD), atomic layer deposition and spray pyrolysis, et al. [28-30]. However, there are still issues regarding the controlling of surface morphology, growth direction and the cost [31-33]. It was reported that mist CVD had advantages on the film deposition such as high uniformity, high reproducibility, simplicity, easy to control, and low cost [34-37].

In our previous research, we had successfully used the mist CVD method to fabricate the $\mathrm{TiO}_{2}$ film [38,39]. In this research, we planned to apply the mist CVD method to synthesize aluminum-doped $\mathrm{ZnO}(\mathrm{AZO})$ thin film. The effect of $\mathrm{Al}$ doping ratios on the properties of films was investigated, and the photocatalytic activity of AZO films was investigated as well.

\section{Experiments}

\subsection{Deposition of AZO Films}

AZO thin films (300 nm thick) were fabricated on the glass substrate by the mist CVD method. A solution of mixed precursor was prepared by dissolving the zinc acetate $(0.04 \mathrm{~mol} / \mathrm{L})$ and aluminum acetylacetonate in water and methanol $(90 \mathrm{~mL}: 10 \mathrm{~mL})$. The mist droplets of precursor solution were generated from the solution chamber by ultrasonic transducer at $2.4 \mathrm{MHz}$, and the droplets transferred to the reaction chamber by nitrogen gas serving as both carrier gas $(2.5 \mathrm{~L} / \mathrm{min})$ and dilution gas $(4.5 \mathrm{~L} / \mathrm{min})$. The substrate was set up in the fine channel of the reaction chamber, which was heated and kept at $400{ }^{\circ} \mathrm{C}$ during the deposition process. In order to investigate the effect of $\mathrm{Al}$ doping ratios on structural and optical properties of AZO films, the doping ratios of $\mathrm{Al}$ were set as $1 \mathrm{wt} \%$ to $5 \mathrm{wt} \%$ for comparison. The deposition conditions are summarized in Table 1.

Table 1. Deposition conditions of AZO films by the mist CVD method.

\begin{tabular}{cc}
\hline Deposition Parameter & Condition \\
\hline Solute & Zinc acetate, Aluminum acetylacetonate \\
Solvent & Methanol, $\mathrm{H}_{2} \mathrm{O}$ \\
Concentration $(\mathrm{mol} / \mathrm{L})$ & 0.04 \\
Al doping ratio $(\mathrm{wt} \%)$ & $1,2,3,4,5$ \\
Deposition temperature $\left({ }^{\circ} \mathrm{C}\right)$ & 400 \\
Carrier gas, flow rate $(\mathrm{L} / \mathrm{min})$ & 2.5 \\
Dilution gas, flow rate $(\mathrm{L} / \mathrm{min})$ & 4.5 \\
\hline
\end{tabular}

\subsection{Photodegradation Process}

The photocatalytic measurements of AZO films were carried out in a glass beaker at room temperature. The methyl red (MR) solution with concentration of $1 \times 10^{-5} \mathrm{~mol} / \mathrm{L}$ and volume of $70 \mathrm{~mL}$ was prepared, and stirred by wrapping the aluminum foil to prevent the light for $30 \mathrm{~min}$ prior to the irradiation. The deposited AZO films with different Al doping ratios were submerged in the MR solution individually and irradiated under an ultraviolet light with a wavelength of $254 \mathrm{~nm}$ for $5 \mathrm{~h}$ during the measurement process. In order to analyze the degradation rate as the function of reaction time, the irradiated solution was taken out at each $1 \mathrm{~h}$ interval.

\subsection{Characterization}

The thicknesses of AZO films were measured by spectroscopic ellipsometry (WVASE32, J.A. Woollam, Co., Inc., Lincoln, CA, USA). The morphologies of AZO films were evaluated by field emission scanning electron microscopy (FE-SEM, SU-8020, Hitachi, Tokyo, Japan) and atomic force microscope (AFM, Nano-R2, Pacific Nanotechnology, Santa Clara, CA, USA). The structural properties of $\mathrm{AZO}$ thin films were investigated by grazing incidence X-ray diffraction (GIXRD, ATX-G, Rigaku, Tokyo, Japan). A UV-visible spectrophotometer (U-4100, Hitachi, Tokyo, Japan was used to evaluate the optical properties of AZO films, as well as the absorption spectra of MR solution. All of the measurements were carried out at room temperature. 


\section{Results and Discussion}

The AFM images of AZO films deposited with different $\mathrm{Al}$ doping ratios by the mist CVD method are shown in Figure 1. The scanning area was $5 \times 5\left(\mu \mathrm{m}^{2}\right)$. It was observed that the root mean square (RMS) surface roughness of AZO films decreased from $6.4 \mathrm{~nm}$ to $3.7 \mathrm{~nm}$ as the $\mathrm{Al}$ doping ratio increased from $1 \mathrm{wt} \%$ to $2 \mathrm{wt} \%$, then slightly increased from $4.6 \mathrm{~nm}$ to $9.7 \mathrm{~nm}$ as the Al ratios increased from $3 \mathrm{wt} \%$ to $5 \mathrm{wt} \%$. The lowest RMS value of AZO films was obtained at an Al doping ratio of $2 \mathrm{wt} \%$. The RMS values of AZO films are summarized in Table 2.

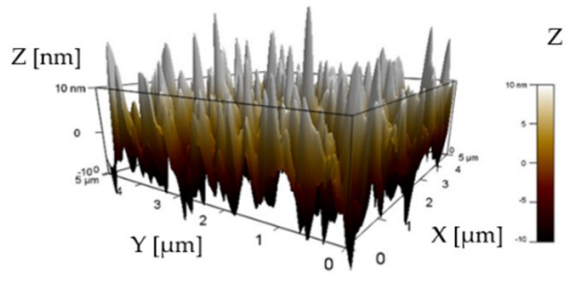

(a)

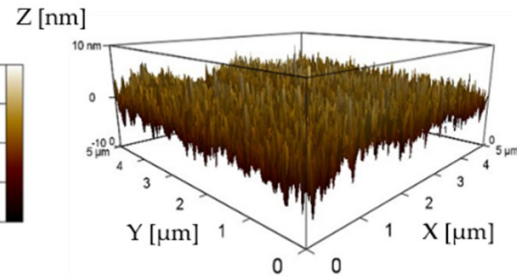

(b)
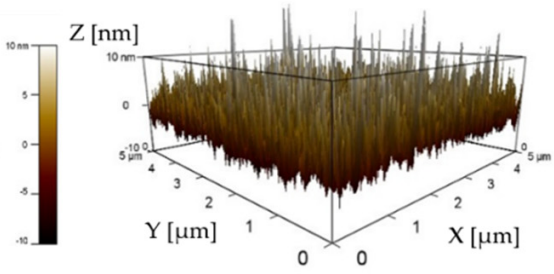

(c)

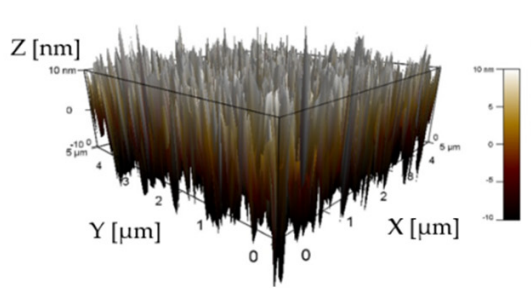

(d)

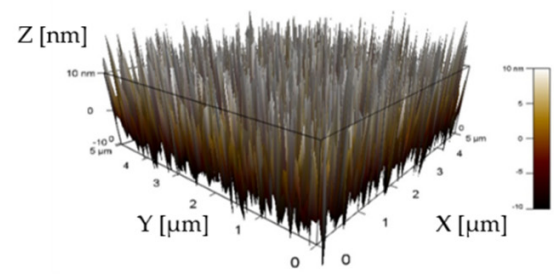

(e)

Figure 1. AFM images of $\mathrm{AZO}$ films with different $\mathrm{Al}$ doping ratios by the mist CVD method: (a) $1 \mathrm{wt} \% \mathrm{Al}$, (b) $2 \mathrm{wt} \% \mathrm{Al}$, (c) $3 \mathrm{wt} \% \mathrm{Al}$, (d) $4 \mathrm{wt} \% \mathrm{Al}$, and (e) $5 \mathrm{wt} \% \mathrm{Al}$.

Table 2. The RMS roughness of AZO films.

\begin{tabular}{cc}
\hline Al Doping Ratio (wt \%) & RMS Roughness (nm) \\
\hline 1 & 6.4 \\
2 & 3.7 \\
3 & 4.6 \\
4 & 8.8 \\
5 & 9.7 \\
\hline
\end{tabular}

The GIXRD patterns of AZO films deposited with different Al doping ratios by the mist CVD method are shown in Figure 2. The (101) peak was the dominant peak for the AZO films deposited with $\mathrm{Al}$ doping ratios of $1 \mathrm{wt} \%$ to $3 \mathrm{wt} \%$, which meant that the growth of $\mathrm{ZnO}$ film exhibited the highly preferred orientation along the (101) crystal plane. Three diffraction peaks of (100), (002) and (101) were observed in the AZO films deposited with an Al doping ratio of $1 \mathrm{wt} \%$. The (100) and (002) peaks became weaker when the $\mathrm{Al}$ doping ratio was increased to $2 \mathrm{wt} \%$, then disappeared when the Al doping ratios were increased to $3 \mathrm{wt} \%$. No diffraction peaks were observed on AZO films when the $\mathrm{Al}$ doping ratios were increased to $4 \mathrm{wt} \%$ and $5 \mathrm{wt} \%$, indicating that the obtained films were amorphous.

The average crystallite size along the (101) crystal plane for AZO films was calculated using Debye-Scherrer's formula [40]. The crystallite size of AZO films was significantly reduced from $31.82 \mathrm{~nm}$ to $13.56 \mathrm{~nm}$ when the $\mathrm{Al}$ doping ratio was increased from $1 \mathrm{wt} \%$ to $3 \mathrm{wt} \%$. 


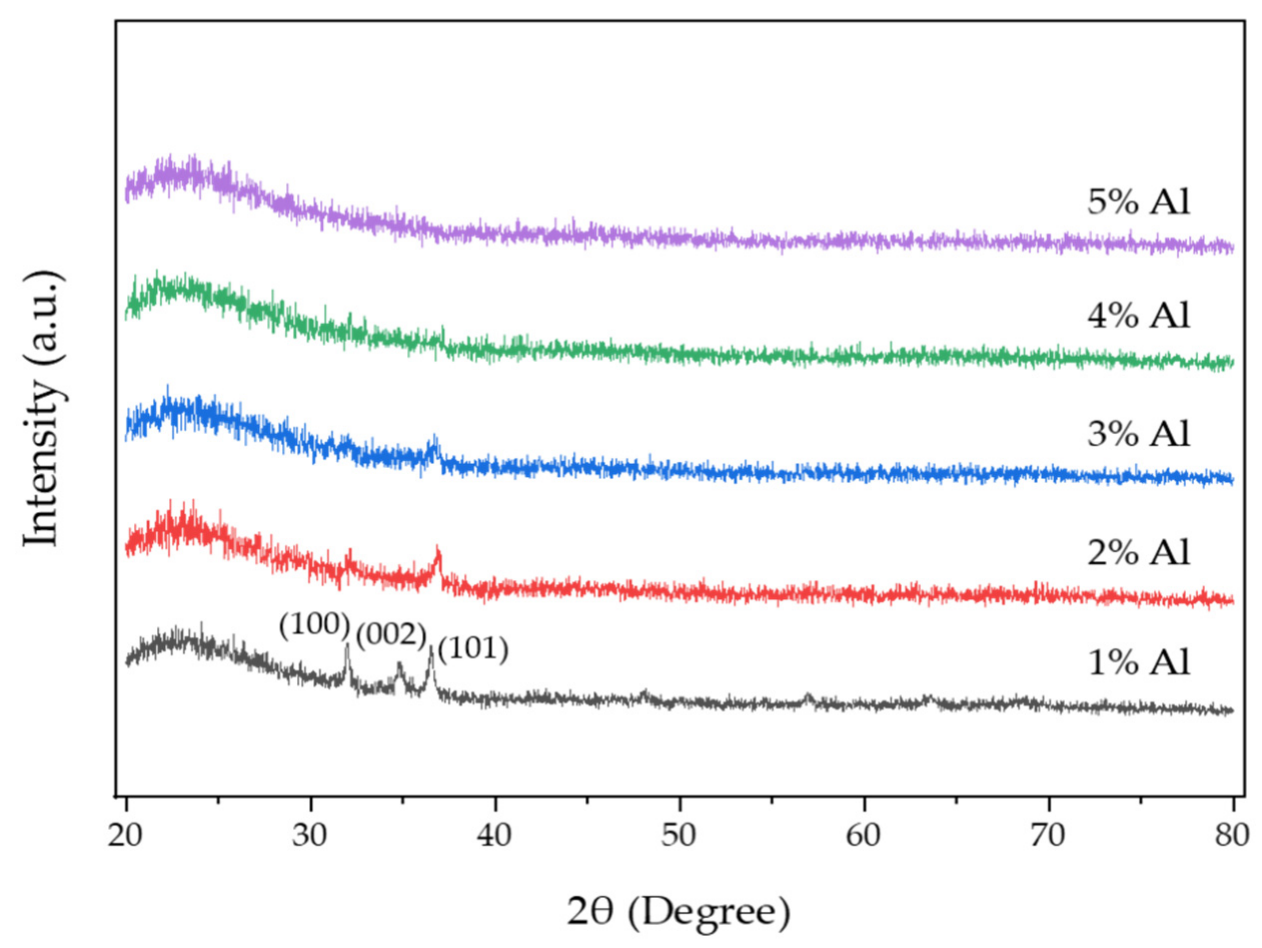

Figure 2. GIXRD patterns of AZO films with different $\mathrm{Al}$ ratios by the mist CVD method.

Using the texture coefficient (TC) (hkl) formula [41], the preferred orientation of the (hkl) plane for AZO film could be determined. The TC values of AZO films calculated based on the XRD data from $\mathrm{Al}$ ratios of $1 \mathrm{wt} \%$ to $3 \mathrm{wt} \%$ are shown in Table 3. From the $\mathrm{TC}$ value results, it was confirmed that the TC value of (002) peak only existed at an $\mathrm{Al}$ doping ratio of $1 \mathrm{wt} \%$. The TC value of the (100) peak was significantly reduced when the Al ratio was increased from $1 \mathrm{wt} \%$ to $3 \mathrm{wt} \%$. Compared to the TC value of (002) and (100) orientations, the TC value of (101) peak was the dominated orientation for all three kinds of AZO films, which meant that the preferred growth of AZO films was (101) crystal plane.

Table 3. Texture coefficient values of AZO films deposited with different $\mathrm{Al}$ ratios.

\begin{tabular}{cccc}
\hline Al Doping Ratio (wt \%) & TC (100) & TC (002) & TC (101) \\
\hline 1 & 2.785 & 1.542 & 3 \\
2 & 0.126 & - & 0.732 \\
3 & 0.117 & - & 0.654 \\
\hline
\end{tabular}

Figure 3 shows the SEM images of AZO films deposited with different $\mathrm{Al}$ doping ratios by the mist CVD method. It was clearly observed that the surface morphologies were significantly changed with increased $\mathrm{Al}$ doping ratios. The intertwined nanosheet structures were observed only at $\mathrm{Al}$ doping ratios of $1 \mathrm{wt} \%$ and $2 \mathrm{wt} \%$. The length of the nanosheets were significantly reduced, and the structures were changed into uniform particles as $\mathrm{Al}$ doping ratios increased from $3 \mathrm{wt} \%$ to $5 \mathrm{wt} \%$. The reason for the structure change might be because of the corresponding variation in the lattice constants of $\mathrm{ZnO}$ films influenced by the $\mathrm{Al}$ doping ratios. With the increase in $\mathrm{Al}$ doping ratios, there was much $\mathrm{Al}^{3+}$ (ionic radius $0.53 \AA$ ) substituted into $\mathrm{ZnO}$ film instead of $\mathrm{Zn}^{2+}$ (ionic radius $0.74 \AA$ ), which can lead to the structure distortion due to the different ionic radius. 

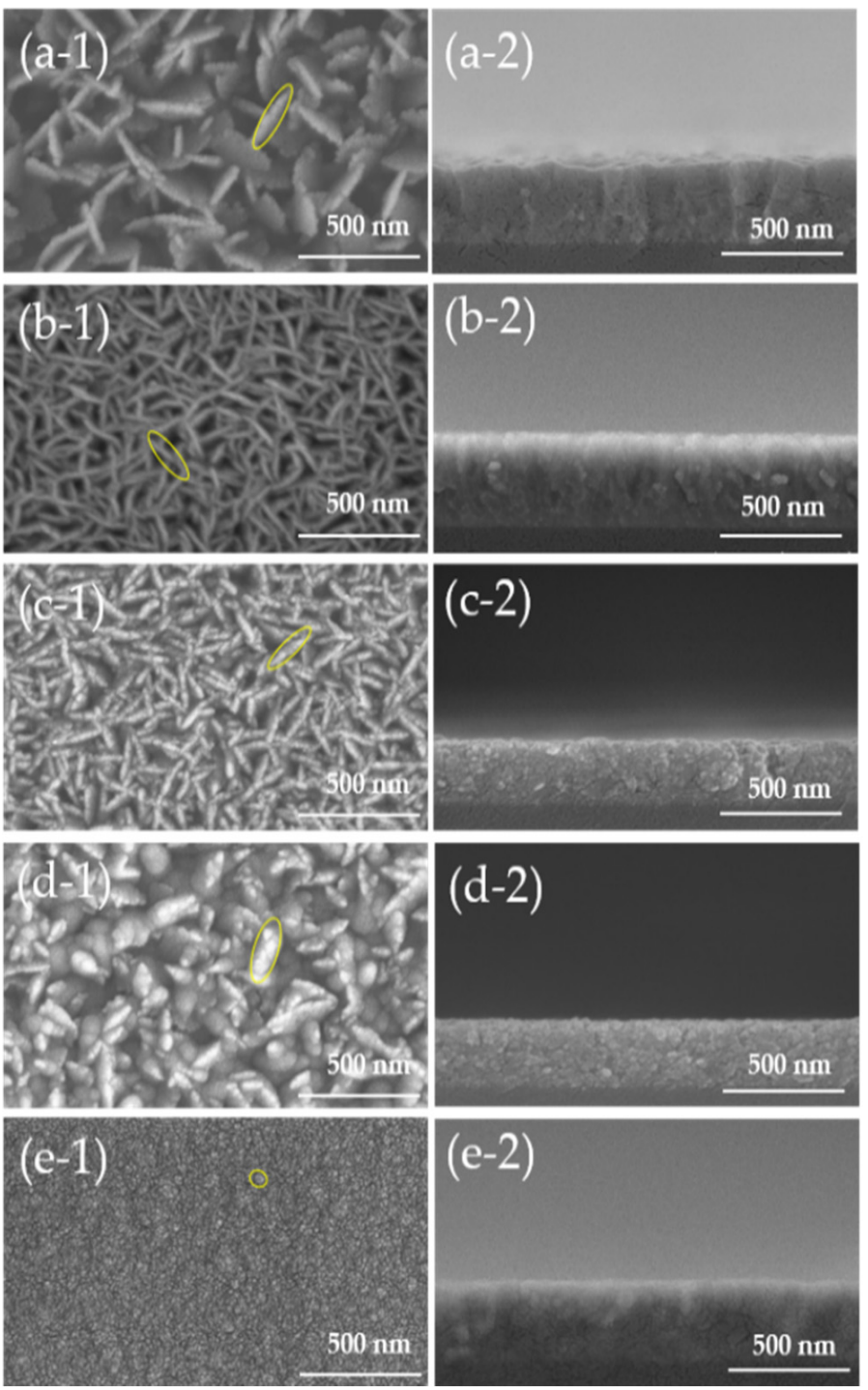

Figure 3. SEM images of $\mathrm{AZO}$ films with different $\mathrm{Al}$ doping ratios by the mist CVD method. (a) $1 \mathrm{wt} \%$ $\mathrm{Al}$, (b) $2 \mathrm{wt} \% \mathrm{Al}$, (c) $3 \mathrm{wt} \% \mathrm{Al}$, (d) $4 \mathrm{wt} \% \mathrm{Al}$, and (e) $5 \mathrm{wt} \% \mathrm{Al}$ : (1) top view, and (2) cross-section view).

EDX measurement was carried out in order to evaluate the elemental composition of deposited $\mathrm{AZO}$ films with different $\mathrm{Al}$ doping ratios by the mist CVD method. The variation of the atomic percentages of $\mathrm{Al} / \mathrm{Zn}, \mathrm{Al} / \mathrm{O}, \mathrm{Zn} / \mathrm{O}$, and $(\mathrm{Al}+\mathrm{Zn}) / \mathrm{O}$ are shown in Figure 4. It was found that the atomic ratio of $\mathrm{Al} / \mathrm{Zn}$ was significantly increased as the $\mathrm{Al}$ ratios were increased from $1 \mathrm{wt} \%$ to $5 \mathrm{wt} \%$, which meant that more $\mathrm{Al}$ ions were doped into $\mathrm{ZnO}$, the maximum value was at $\mathrm{Al}$ doping ratio of $3 \mathrm{wt} \%$. The atomic ratios of $\mathrm{Al} / \mathrm{O}$ and $(\mathrm{Al}+\mathrm{Zn}) / \mathrm{O}$ slightly increased; in contrast, that of $\mathrm{Zn} / \mathrm{O}$ gradually decreased as the $\mathrm{Al}$ ratios were increased from $1 \mathrm{wt} \%$ to $5 \mathrm{wt} \%$. The atomic ratios of $\mathrm{Zn} / \mathrm{O}$ were greater than $\mathrm{Al} / \mathrm{O}$ when the $\mathrm{Al}$ doping ratios were at $1 \mathrm{wt} \%$ and $2 \mathrm{wt} \%$, which meant that the $\mathrm{Zn}-\mathrm{O}$ bond was dominated to form $\mathrm{ZnO}$. When the $\mathrm{Al}$ doping ratios increased to $3 \mathrm{wt} \%$ and furthermore, the atomic ratio of $\mathrm{Al} / \mathrm{O}$ was greater than that of $\mathrm{Zn} / \mathrm{O}$, which indicated that the $\mathrm{Al}$ ions served as the oxidizing agent to replace the $\mathrm{Zn}$ ion sites incorporated to oxygen ions to form $\mathrm{AZO}$ and $\mathrm{Al}_{1-\mathrm{x}} \mathrm{O}_{\mathrm{x}}$. However, the atomic ratio of $(\mathrm{Al}+\mathrm{Zn}) / \mathrm{O}$ increased and reached a maximum at $2 \mathrm{wt} \%$, then significantly decreased and stayed at nearly level from $3 \mathrm{wt} \%$ to $5 \mathrm{wt} \%$, which might be due to the saturation of oxygen ions bonding. 


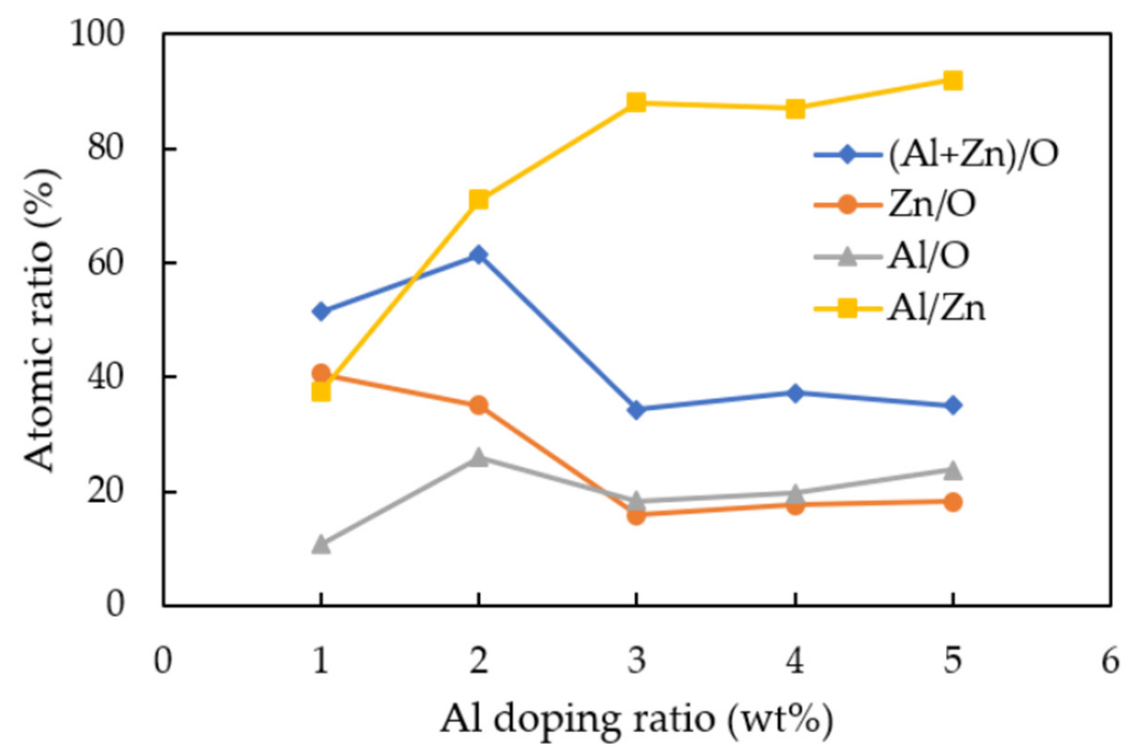

Figure 4. Variations of $\mathrm{Al} / \mathrm{Zn}, \mathrm{Al} / \mathrm{O}, \mathrm{Zn} / \mathrm{O}$, and $(\mathrm{Al}+\mathrm{Zn}) / \mathrm{O}$ atomic ratios calculated from $\mathrm{EDX}$ analysis of $\mathrm{AZO}$ films deposited with different $\mathrm{Al}$ ratios by the mist $\mathrm{CVD}$ method.

The mechanism of growth direction of $\mathrm{AZO}$ films deposited with different $\mathrm{Al}$ ratios by the mist CVD method are shown in schematic diagram (Figure 5). The growth of AZO films mainly includes three stages: (a) mist droplets generation, (b) nucleation, and (c) growth process. In the first stage, the mixed precursors of zinc acetate (ZA) and aluminum acetylacetonate (AA) were prepared in the solution chamber and transformed into mist droplets by the ultrasonic transducer.

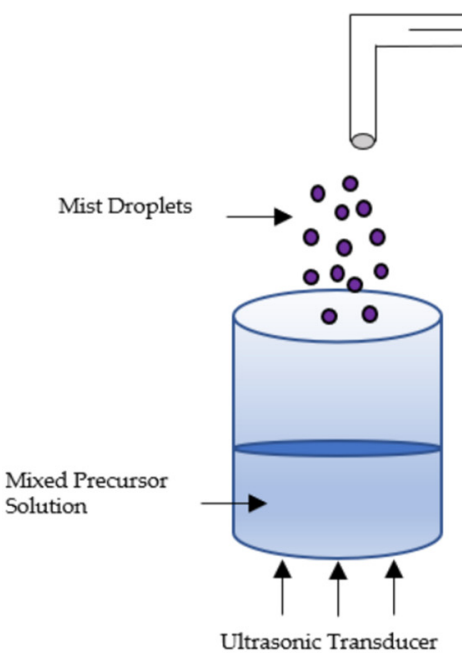

(a)

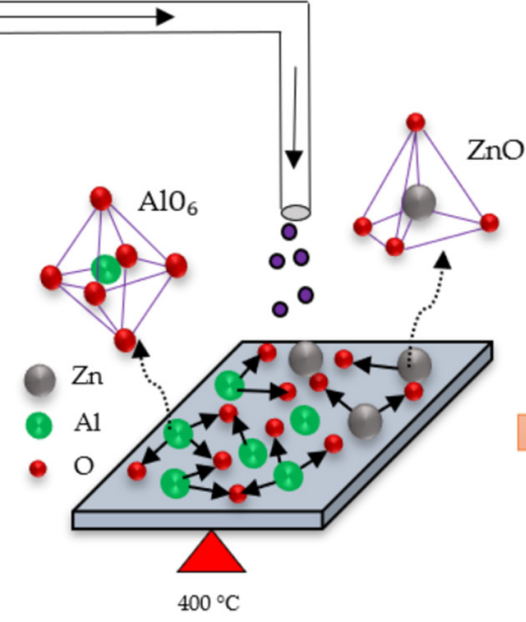

(b)
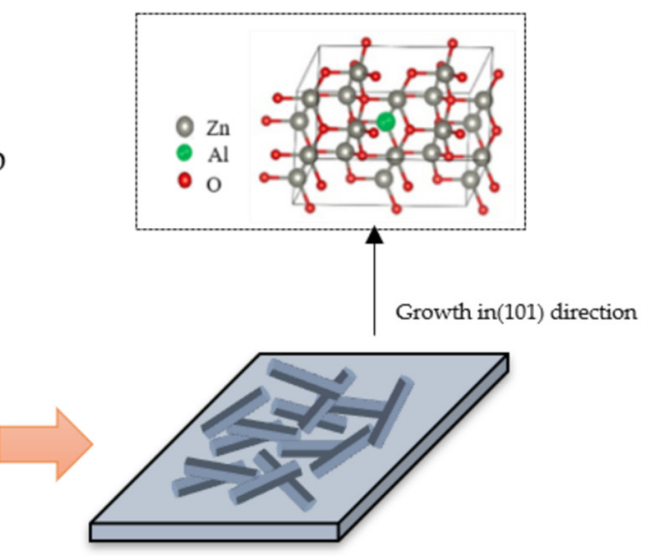

(c)

Figure 5. Growth model of AZO films deposited with different $\mathrm{Al}$ ratios by the mist CVD method: (a) mist droplets generation, (b) nucleation, and (c) growth process.

In the second stage, the mist droplets including the ZA and AA were transported to the reaction chamber, in which the fine channel substrate was preheated and kept at $400{ }^{\circ} \mathrm{C}$. During the nucleation process, the substrate was heated to $400{ }^{\circ} \mathrm{C}$, which is greater than the decomposition temperature of $\mathrm{AA}\left(193^{\circ} \mathrm{C}\right)$ and $\mathrm{ZA}\left(237^{\circ} \mathrm{C}\right)$. The decomposed $\mathrm{Al}$ ions were much easier to generate than $\mathrm{Zn}$ ions to bond with the oxygen ions due to the fact that the decomposition temperature of AA was lower than ZA. Moreover, it was already reported that the bonding mode of $\mathrm{AlO}_{6}$ could be confirmed when the deposition temperature was 
greater than $350{ }^{\circ} \mathrm{C}$ during the mist deposition process [42]. Therefore, in this experiment, the $\mathrm{Al}-\mathrm{O}$ bonds were becoming dominant and forming $\mathrm{Al}_{1-\mathrm{x}} \mathrm{O}_{\mathrm{x}}$ with the increase in $\mathrm{Al}$ doping ratios at the growth temperature of $400{ }^{\circ} \mathrm{C}$, resulting in the suppression of crystal nucleation of $\mathrm{ZnO}$.

In the final stage, $\mathrm{ZnO}$ was formed with the preferential growth in the (101) direction, which might be due to its fastest growth compared to the other growth directions [43]. Therefore, the intertwined nanosheet structures were formed when the Al ratios increased from $1 \mathrm{wt} \%$ to $3 \mathrm{wt} \%$.

The optical transmittance of $\mathrm{AZO}$ films with different $\mathrm{Al}$ doping ratios by the mist CVD method are shown in Figure 6a. The transmittance of all AZO films was more than $80 \%$ in the visible region. Moreover, the blue-shift of the absorption edge was observed, which meant that the energy gaps slightly increased when the Al ratios were increased from $1 \mathrm{wt} \%$ to $5 \mathrm{wt} \%$.

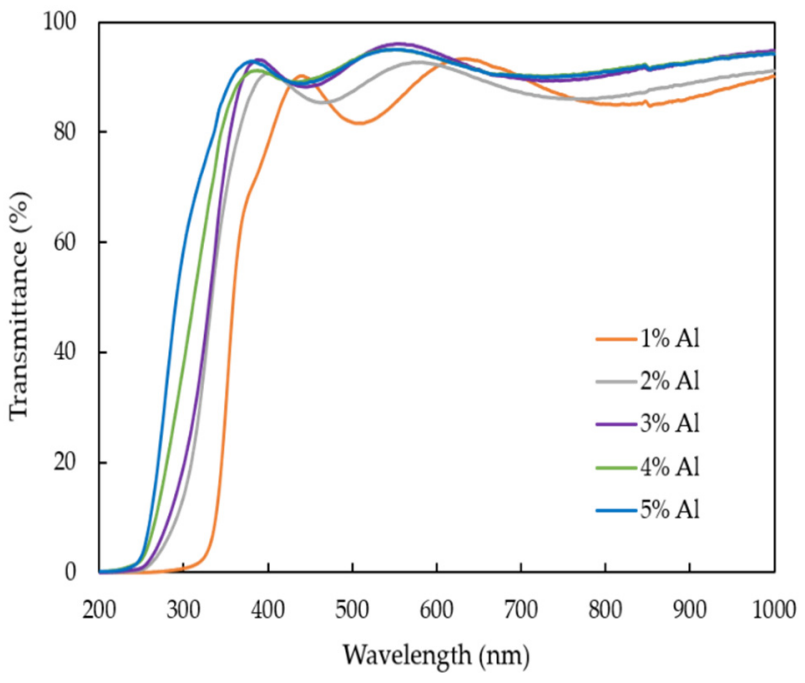

(a)

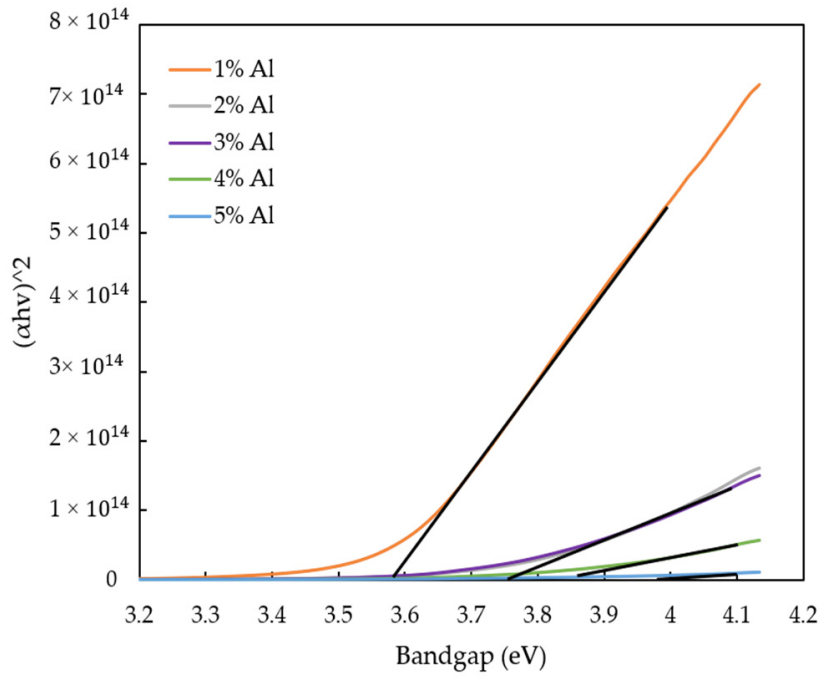

(b)

Figure 6. (a) Optical transmittance spectra, and (b) Variation of bandgap in AZO films deposited with different $\mathrm{Al}$ ratios by the mist CVD method.

The optical bandgap variations of AZO film by plotting $(\alpha \mathrm{hv})^{2}$ versus energy of photon (hv) with the different $\mathrm{Al}$ ratios are described in Figure $6 \mathrm{~b}$. The optical bandgaps of AZO films were calculated by Tauc's plot equation [44], as in the following;

$$
(\alpha h v)^{2}=A\left(h v-E_{g}\right)
$$

where A is the constant, $\mathrm{h}$ is Planck's constant, $\mathrm{v}$ is the photon frequency and $\mathrm{E}_{\mathrm{g}}$ is the optical bandgap. The optical bandgaps increased from $3.58 \mathrm{eV}$ to $3.87 \mathrm{eV}$ when the $\mathrm{Al}$ doping ratios were increased from $1 \mathrm{wt} \%$ to $5 \mathrm{wt} \%$.

Figure 7a shows the absorption spectra of MR solution for AZO films deposited with different $\mathrm{Al}$ doping ratios by the mist CVD method. It was observed that the intensities of absorption spectra decreased between $475 \mathrm{~nm}$ and $700 \mathrm{~nm}$ when the Al ratios were increased from $1 \mathrm{wt} \%$ to $4 \mathrm{wt} \%$, as compared with the original MR solution (black line). The obtained results indicate that photodegradation efficiency was achieved. The lowest absorption intensity was obtained at $\mathrm{Al}$ doping ratio of $2 \mathrm{wt} \%$. When the $\mathrm{Al}$ ratios increased to $5 \mathrm{wt} \%$, the absorption spectrum was slightly higher than the original solution, which meant that there was no photodegradation efficiency. 


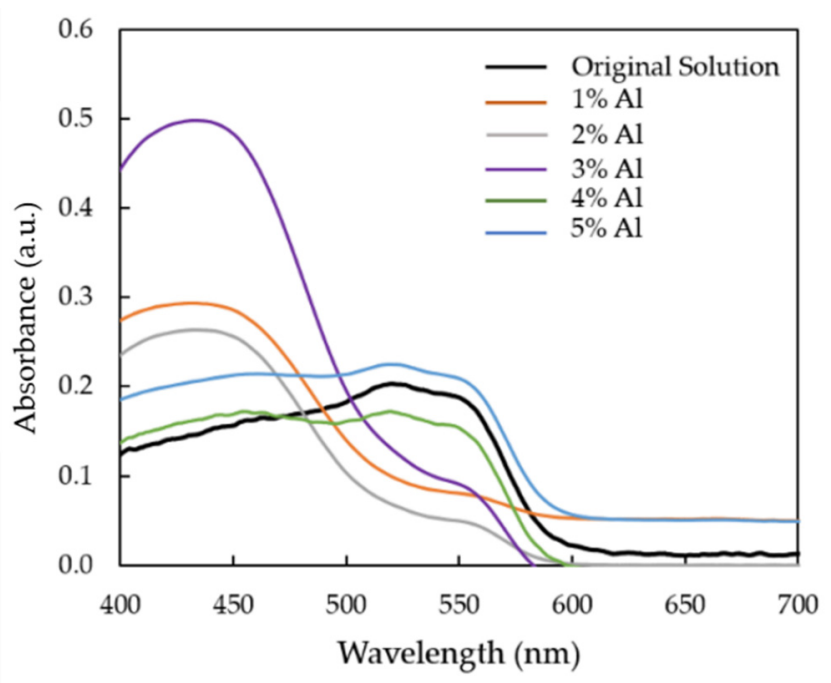

(a)

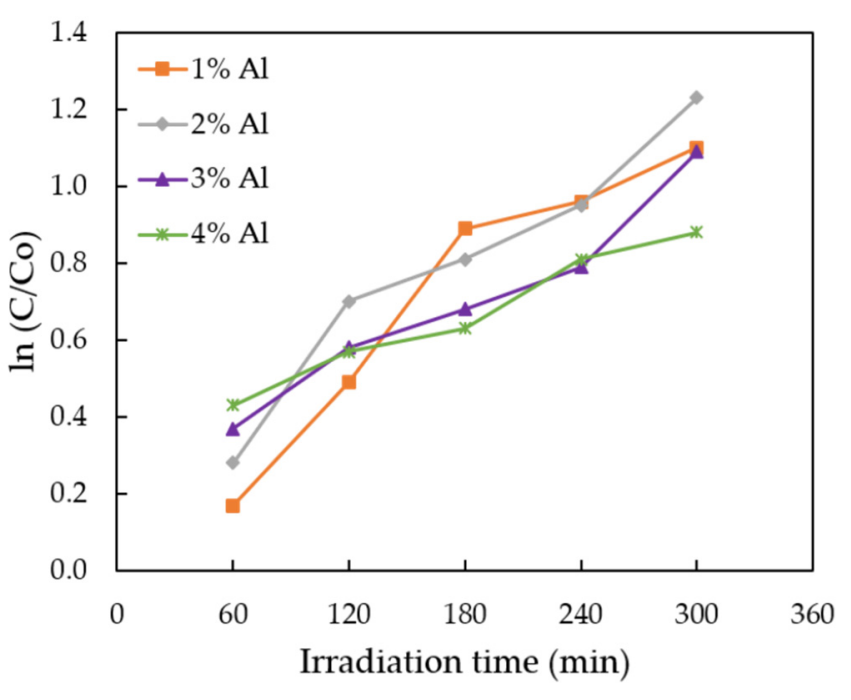

(b)

Figure 7. (a) The absorption spectra of MR solution for AZO films deposited with different Al doping ratios; and (b) plot of $\ln (\mathrm{C} / \mathrm{Co})$ versus the reaction time.

In order to calculate the degradation rate of obtained AZO films, the absorption band at $520 \mathrm{~nm}$ was selected, which corresponds to the red color of MR solution. Based on the variations in the intensity of absorption spectra, the rates of photocatalytic degradation are presented in Figure 7b. Langmuir-Hinshelwood ( $\mathrm{L}-\mathrm{H})$ mode [45] can be used to describe the degradation kinetic of various organic dyes. The adsorption rate may be represented in terms of the coverage ratio of adsorbed reactants on the photocatalyst surface. The rate of reaction, $R$, can be described as Equation (2) [46].

$$
\mathrm{R}=-\mathrm{dC} / \mathrm{dt}=\mathrm{k}_{\mathrm{r}} \theta
$$

where $C$ is the concentration of the reactant, $t$ is the reaction time, $k_{r}$ is the reaction rate constant, and $\theta$ is the coverage ratio of reactants.

According to the adsorption theory, the adsorption capacity and concentration of reactant correspond to the coverage ratio of the reactant. In order to determine the adsorption capacity, the adsorption coefficient of reactant was defined as $\mathrm{K}$. Therefore, the $\theta$ can be expressed as Equation (3) [45].

$$
\theta=\mathrm{KC} /(1+\mathrm{KC})
$$

Then, Equation (3) can be substituted to Equation (2); the reaction rate, $\mathrm{R}$ can be expressed as Equation (4).

$$
\mathrm{R}=-\mathrm{dC} / \mathrm{dt}=\mathrm{k}_{\mathrm{r}} \mathrm{KC} /(1+\mathrm{KC})
$$

For pseudo first-order reaction, KC, is smaller than 1 [47], then Equation (4) can be expressed as,

$$
\mathrm{R}=-\mathrm{dC} / \mathrm{dt}=\mathrm{k}_{\mathrm{r}} \mathrm{KC}
$$

Equation (5) can be described as per the Integration Law, as follows;

$$
\begin{gathered}
\ln (\mathrm{C})-\ln (\mathrm{Co})=\mathrm{kt}, \\
\ln (\mathrm{C} / \mathrm{Co})=\mathrm{kt}
\end{gathered}
$$

where $\mathrm{k}$ is the first-order reaction rate constant.

Figure $7 \mathrm{~b}$ shows the plot of $\ln (\mathrm{C} / \mathrm{Co})$ as a function of UV irradiation time for photocatalytic degradation of MR solution for AZO films with different Al doping ratios. The value of Co was determined as the original absorbance of MR solution and the value of 
$\mathrm{C}$ was determined as the absorbance of each $\mathrm{AZO}$ film with different $\mathrm{Al}$ doping ratios. According to the Langmuir-Hinshelwood $(\mathrm{L}-\mathrm{H})$ mode, the higher value of first-order rate corresponds to the higher photocatalytic efficiency [48].

In order to calculate the first-order reaction rate constant $k$, the following equation can be rewritten from Equation (6).

$$
\mathrm{k}=\ln (\mathrm{C} / \mathrm{Co}) / \mathrm{t}
$$

According to Equation (7), the calculated first-order reaction rate increased from $0.003 \mathrm{~min}^{-1}$ to $0.004 \mathrm{~min}^{-1}$ when the $\mathrm{Al}$ ratios was increased from $1 \mathrm{wt} \%$ to $2 \mathrm{wt} \%$, then decreased from $0.0005 \mathrm{~min}^{-1}$ to $0.0003 \mathrm{~min}^{-1}$ when the $\mathrm{Al}$ ratios were increased from $3 \mathrm{wt} \%$ to $4 \mathrm{wt} \%$. The highest reaction rate was observed from the AZO film with Al doping ratio of $2 \mathrm{wt} \%$.

\section{Conclusions}

The $\mathrm{Al}$ was successfully doped into $\mathrm{ZnO}$ film with controllable ratios by the mist CVD method. It was confirmed that the properties of AZO films were significantly influenced by the $\mathrm{Al}$ ratios. The highly preferred orientation of AZO films was along the (101) crystal plane when the $\mathrm{Al}$ doping ratios were increased from $1 \mathrm{wt} \%$ to $3 \mathrm{wt} \%$. The best crystallinity and the lowest surface roughness were obtained at an Al doping ratio of $2 \mathrm{wt} \%$. The crystal structures of $\mathrm{AZO}$ were transformed from intertwined nanosheets to uniform particles as the $\mathrm{Al}$ doping ratios increased. The growth mechanism revealed that $\mathrm{Al}-\mathrm{O}$ bonds were enhanced and greater than the $\mathrm{Zn}-\mathrm{O}$ bond when the $\mathrm{Al}$ doping ratios increased at the deposition temperature of $400{ }^{\circ} \mathrm{C}$ during the mist CVD process. The transmittance of all AZO films was higher than the $80 \%$ in the visible region. The AZO film with Al doping ratio of $2 \mathrm{wt} \%$ showed the highest photodegradation efficiency and the highest value of first-order reaction rate of $0.004 \mathrm{~min}^{-1}$. The obtained AZO films can be expected to have applications in environmental purification processes.

Author Contributions: Conceptualization, H.S.W.; methodology, H.S.W.; investigation, H.S.W.; data analysis, H.S.W.; writing—original draft preparation, H.S.W.; writing-review and editing, C.L.; visualization, C.L.; supervision, C.L.; project administration, C.L.; funding acquisition, C.L. All authors have read and agreed to the published version of the manuscript.

Funding: This research received no external funding.

Institutional Review Board Statement: Not applicable.

Informed Consent Statement: Not applicable.

Data Availability Statement: All required data are provided within the manuscript.

Conflicts of Interest: The authors declare no conflict of interest.

\section{References}

1. Hashimoto, K.; Irie, H.; Fujishima, A. TiO 2 photocatalysis: A historical overview and future prospects. Jpn. J. Appl. Phys. 2005, 44, 8269-8285. [CrossRef]

2. Ibhadon, A.O.; Fitzpatrick, P. Heterogeneous photocatalysis: Recent advances and applications. Catalysts 2013, 3, 189-218. [CrossRef]

3. Teoh, W.Y.; Scott, J.A.; Amal, R. Progress in heterogenous photocatalysis: From classical radical chemistry to engineering nanomaterials and solar reactors. J. Phys. Chem. Lett. 2012, 3, 629-639. [CrossRef]

4. Bhatkhande, D.S.; Pangarkar, V.G.; Beenackers, A.A.C.M. Photocatalytic degradation for environmental applications-A review. J. Chem. Technol. Biotechnol. 2001, 77, 102-116. [CrossRef]

5. Minero, C.; Pelizzatti, E.; Sega, M.; Friberg, S.E.; Sjoblom, J. The role of humid substances in photocatalytic degradation of water contaminants. J. Dispers. Sci. Technol. 1999, 20, 643-661. [CrossRef]

6. Pirkanniemi, K.; Sillanpa, M. Heterogeneous water phase catalysis as an environmental application: A review. Chemosphere 2002, 48, 1047-1060. [CrossRef]

7. Maeda, K.; Domen, K. Photocatalytic water splitting: Recent progress and future challenges. J. Phys. Chem. Lett. 2010, 1, 2655-2661. [CrossRef] 
8. Chen, D.; Ray, A.K. Removal of toxic metal ions from wastewater by semiconductor photocatalysis. Chem. Eng. Sci. 2001, 56, 1561-1570. [CrossRef]

9. Mills, A.; Lehunte, S.L. An overview of semiconductor photocatalysis. J. Photochem. Photobiol. A Chem. 1997, 108, 1-35. [CrossRef]

10. Gerischer, H. Electrochemical behavior of semiconductors under illumination. J. Electrochem. Soc. 1966, 113, 1174-1182. [CrossRef]

11. Mills, A.; O'Rourke, C.; Moore, K. Powder semiconductor photocatalysis in aqueous solution: An overview of kinetics-based reaction mechanisms. J. Photochem. Photobiol. A 2015, 310, 66-105. [CrossRef]

12. Kanemoto, M.; Shiragami, T.; Pac, C.; Yanagida, S. Semiconductor photocatalysis. 13. Effective photoreduction of carbon dioxide catalyzed by ZnS quantum crystallites with low density of surface defects. J. Phys. Chem. 1992, 96, 3521-3526. [CrossRef]

13. Li, X.; Wen, J.; Low, J.; Fang, Y.; Yu, J. Design and fabrication of semiconductor photocatalyst for photocatalytic reduction of $\mathrm{CO}_{2}$ to solar fuel. Sci. China Mater. 2014, 57, 70-100. [CrossRef]

14. Franco, P.; Sacco, O.; De Marco, I.; Vaiano, V. Zinc oxide nanoparticles obtained by supercritical antisolvent precipitation for the photocatalytic degradation of crystal violet dye. Catalysts 2019, 9, 346. [CrossRef]

15. Vanheusden, K.; Warren, W.L.; Seager, C.H.; Tallant, D.R.; Voigt, J.A.; Gnade, B.E. Mechanisms behind green photoluminescence in ZnO phosphor powders. J. Appl. Phys. 1996, 79, 7983-7990. [CrossRef]

16. Baratto, C.; Comini, E.; Ferroni, M.; Faglia, G.; Sberveglieri, G. Plasma-induced enhancement of UV photoluminescence in ZnO nanowires. CrystEngComm 2013, 15, 7981-7986. [CrossRef]

17. Seo, Y.S.; Oh, S.G. Controlling the recombination of electron-hole pairs by changing the shape of ZnO nanorods via sol-gel method using water and their enhanced photocatalytic properties. Korean J. Chem. Eng. 2019, 36, 2118-2124. [CrossRef]

18. Gaspar, D.; Pereira, L.; Gehrke, K.; Galler, B.; Fortunato, E.; Martins, R. High mobility hydrogenated zinc oxide thin films. Sol. Energy Mater. Sol. Cells 2017, 163, 255-262. [CrossRef]

19. Meyer, B.K.; Alves, H.; Hofmann, D.M.; Kriegseis, W.; Forster, D.; Bertram, F.; Christen, J.; Hoffmann, A.; Straßburg, M.; Dworzak, M. Bound exciton and donor-acceptor pair recombinations in ZnO. Phys. Status Solidi (b) 2004, 241, 231-260. [CrossRef]

20. Mukhopadhyay, S.; Das, P.P.; Maity, S.; Ghosh, P.; Devi, P.S. Solution grown ZnO rods: Synthesis, characterization and defect mediated photocatalytic activity. Appl. Catal. B Environ. 2015, 165, 128-138. [CrossRef]

21. He, J.; Zhang, Y.; Guo, Y.; Rhodes, G.; Yeom, J.; Li, H.; Zhang, W. Photocatalytic degradation of cephalexin by ZnO nanowires under simulated sunlight: Kinetics, influencing factors, and mechanisms. Environ. Int. 2019, 132, 105105. [CrossRef]

22. Ong, C.B.; Ng, L.Y.; Mohammad, A.W. A review of $\mathrm{ZnO}$ nanoparticles as solar photocatalysts: Synthesis, mechanisms and applications. Renew. Sustain. Energy Rev. 2018, 81, 536-551. [CrossRef]

23. Luevano-Hipolito, E.; Martinez-de la Cruz, A.; Cuellar, E.L. Performance of ZnO synthesized by sol-gel as photocatalyst in the photooxidation reaction of NO. Environ. Sci. Pollut. Res. 2016, 24, 6361-6371. [CrossRef] [PubMed]

24. Ebrahimi, R.; Hossienzadeh, K.; Maleki, A.; Ghanbari, R.; Rezaee, R.; Safari, M.; Shahmoradi, B.; Daraei, H.; Jafari, A.; Yetilmezsoy, K.; et al. Effects of doping zinc oxide nanoparticles with transition metals $(\mathrm{Ag}, \mathrm{Cu}, \mathrm{Mn}$ ) on photocatalytic degradation of Direct Blue 15 dye under UV and visible light irradiation. J. Environ. Health Sci. Eng. 2019, 17, 479-492. [CrossRef] [PubMed]

25. Yu, F.; Wang, B.; Hu, H.; Li, H.; Song, T.; Xu, B.; He, L.; Duan, H.; Wang, S. The photocatalytic properties of Al-doped ZnO nanotubes decorated with $\mathrm{Cu}_{2} \mathrm{O}$ nanoparticles. Phys. Status Solidi (a) 2019, 216, 1900386. [CrossRef]

26. Ahammed, N.; Hassan, M.S.; Hassan, M. Effects of aluminum (Al) incorporation on structural, optical and thermal properties of ZnO nanoparticles. Mater. Sci. 2018, 36, 419-426. [CrossRef]

27. Mahdavi, R.; Talesh, S.S.A. Sol-gel synthesis, structural and enhanced photocatalytic performance of Al doped $\mathrm{ZnO}$ nanoparticles. Adv. Powder Technol. 2017, 28, 1418-1425. [CrossRef]

28. Lai, F.I.; Yang, J.F.; Hsu, Y.C.; Kuo, S.Y. Location-optoelectronic property correlation in ZnO: Al thin film by RF magnetron sputtering and its photovoltaic application. Materials 2021, 14, 6313. [CrossRef]

29. Tang, P.; Li, B.; Feng, L. The optical and electrical properties of $\mathrm{ZnO}$ : Al thin films deposited at low temperatures by RF magnetron sputtering. Ceram. Int. 2018, 44, 4154-4157. [CrossRef]

30. Jeong, J.-K.; Yun, H.-J.; Yang, S.-D.; Eom, K.-Y.; Chea, S.-W.; Park, J.-H.; Lee, H.-D.; Lee, G.-W. Investigation of atomiclayerdeposited $\mathrm{Al}$-doped $\mathrm{ZnO}$ film for $\mathrm{AZO} / \mathrm{ZnO}$ double-stacked active layer thin-film transistor application. Thin Solid Film. 2017, 638, 89-95. [CrossRef]

31. Kaneva, N.; Stambolova, I.; Blaskov, V.; Dimitriev, Y.; Bojinova, A.; Dushkin, C. A comparative study on the photocatalytic efficiency of $\mathrm{ZnO}$ thin films prepared by spray pyrolysis and sol-gel method. Surf. Coat. Technol. 2011, 207, 5-10. [CrossRef]

32. Wang, Y.; Zhang, X.; Bai, L.; Huang, Q.; Wei, C.; Zhao, Y. Effective light trapping in thin film silicon solar cells from textured Al doped $\mathrm{ZnO}$ substrates with broad surface feature distributions. Appl. Phys. Lett. 2012, 100, 263508. [CrossRef]

33. Jeong, S.H.; Park, G.C.; Choi, J.H.; Lee, C.M.; Lee, S.M.; Seo, T.Y.; Choi, D.H.; Jung, S.B.; Lim, J.H.; Joo, J. Effect of Al incorporation on morphology and electrical conductivity of $\mathrm{ZnO}$ nanorods prepared using hydrothermal method. J. Nanosci. Nanotechnol. 2016, 16, 11272-11276. [CrossRef]

34. Rutthongjan, P.; Liu, L.; Nishi, M.; Sakamoto, M.; Sato, S.; Pradeep, E.K.C.; Dang, G.T.; Kawaharamura, T. Composition control of $\mathrm{Zn}_{1-\mathrm{x}} \mathrm{Mg}_{\mathrm{x}} \mathrm{O}$ thin films grown using mist chemical vapor deposition. J. Appl. Phys. 2019, 58, 035503-035512. [CrossRef]

35. Liu, L.; Suwa, Y.; Sato, S.; Nakasone, Y.; Nishi, M.; Dang, G.T.; Pradeep, E.K.C.; Kawaharamura, T. Study on fabrication of conductive antimony doped tin oxide thin films $\left(\mathrm{SnO}_{x}: \mathrm{Sb}\right)$ by $3 \mathrm{rd}$ generation mist chemical vapor deposition. Jpn. J. Appl. Phys. 2019, 58, 025502-025509. [CrossRef] 
36. Kawaharamura, T. Physics on development of open-air atmospheric pressure thin film fabrication technique using mist droplets: Control of precursor flow. Jpn. J. Appl. Phys. 2014, 53, 05FF08. [CrossRef]

37. Li, X.; Li, C.; Kawaharamura, T.; Wang, D.; Nitta, N.; Furuta, M.; Furuta, H.; Hatta, A. Fabrication of zinc oxide nanostructures by mist chemical vapor deposition. Trans. Mater. Res. Soc. Jpn. 2014, 39, 161-164. [CrossRef]

38. Zhang, Q.; Li, C. Pure anatase phase titanium dioxide films prepared by mist chemical vapor deposition. Nanomaterials $2018,8,827$. [CrossRef] [PubMed]

39. Zhang, Q.; Li, C. Effect of substrates on structural properties of pure anatase phase titanium dioxide thin films prepared by mist chemical vapor deposition. ECS J. Solid State Sci. Technol. 2018, 7, P654-P659. [CrossRef]

40. Rao, T.P.; Santhoshkumar, M.C. Highly oriented (1 0 0) ZnO thin films by spray pyrolysis. Appl. Surf. Sci. 2009, $255,7212-7221$.

41. Patterson, A.L. The Scherrer Formula for X-Ray Particle Size Determination. Phys. Rev. 1939, 56, 978-982. [CrossRef]

42. Kawaharamura, T.; Uchida, T.; Sanada, M.; Furuta, M. Growth and electrical properties of $\mathrm{AlO}_{\mathrm{x}}$ grown by mist chemical vapor deposition. AIP Adv. 2013, 3, 032135-032145.

43. Ramya, M.; Nideep, T.K.; Nampoori, V.P.N.; Kailasnath, M. Solvent assisted evolution and growth mechanism of zero to three dimensional ZnO nanostructures for dye sensitized solar cell applications. Sci. Rep. 2021, 11, 6159-6173. [CrossRef] [PubMed]

44. Tauc, J. Optical properties and electronic structure of amorphous Ge and Si. Mater. Res. Bull. 1968, 3, 37-46. [CrossRef]

45. Langmuir, I. The constitution and fundamental properties of solids and liquids. Part I. Solids. J. Am. Chem. Soc. 1916, 38, 2221-2295. [CrossRef]

46. Kim, S.B.; Hong, S.C. Kinetic study for photocatalytic degradation of volatile organic compounds in air using thin film $\mathrm{TiO}_{2}$ photocatalyst. Appl. Catal. B Environ. 2002, 35, 305-315. [CrossRef]

47. Loghambal, S.; Catherine, A.J.A.; Subash, S.V. Analysis of langmuir-hinshelwood kinetics model for photocatalytic degradation of aqueous direct blue 71 through analytical expression. Int. J. Math. Appl. 2018, 6, 903-913.

48. Golshan, M.; Zare, M.; Goudarzi, G.; Abtahi, M.; Babaei, A.A. Fe $\mathrm{O}_{4} @$ hap-enhanced photocatalytic degradation of acid red 73 in aqueous suspension: Optimization, kinetic, and mechanism studies. Mater. Res. Bull. 2017, 91, 59-67. [CrossRef] 